\title{
Upaya Meningkatkan Kemampuan Guru Dalam Penggunaan Metode Pembelajaran Melalui Supervisi Klinis di SMP Negeri 3 Pasie Raya Tahun Pelajaran 2018
}

\author{
Raudhatul Hayati, S.Ag \\ SMP Negeri 3 Pasie Raya
}

\begin{abstract}
Abstrak
Berdasarkan hasil pengamatan terhadap pelaksanaan supervisi klinis, pada SMP Negeri 3 Pasie Raya Kabupaten Aceh Jaya, diperoleh catatan 1. Guru sudah menguasai seluruh indikator yang dinilai, dengan hasil yang "sangat memuaskan". 2. Kemampuan guru dalam menerapkan metode juga memberikan efek positif terhadap siswa berupa peningkatan motivasi dan keaktifan yang selanjutnya menjadi nilai tambah guna meningkatkan prestasi belajar siswa. 3. Metode pembelajaran yang digunakan sudah sesuai dengan RPP yang disusun. Guru sudah memilih metode yang tepat dan sesuai dengan tujuan pembelajaran. Mengacu hasil pengamatan terhadap kemampuan guru kelas VII dari siklus I hanya mendapat nilai rata-rata 2.55 meningkat menjadi 3,67 di siklus II, sementara kelas VIII dari sebelumnya pada siklus I hanya mendapat nilai ratarata 2,67 berubah menjadi 3,67 pada siklus II dan kelas IX pada siklus I hanya mendapat rata-rata sama dengan kelas VIII yaitu 2,67 berubah menjadi 3,50, dengan predikat semua pada siklus II"sangat memuaskan".
\end{abstract}

\section{Kata kunci : Kemampuan, Guru, Metode, Supervisi Klinis}

\section{PENDAHULUAN}

Undang-Undang RI Nomor 20 Tahun 2003, tentang Sispenas Bab XI Pasal 39 ayat (1), dijelaskan tenaga kependidikan bertugas melaksanakan administrasi, pengelolaan, pengembangan, dan pelayanan teknis untuk menunjang proses pendidikan dan satuan pendidikan. Guru memiliki posisi yang sangat penting dan menentukan keberhasilan pendidikan. Guru berada pada lini paling depan dalam keterlaksanaan proses pembelajaran di sekolah. Guru merupakan orang yang paling bertanggung jawab atas kualitas dan kebermaknaan proses pembelajaran di dalam kelas. Oleh karena itu, kinerja guru sangat berpengaruh terhadap keberhasilan sebuah proses pembelajaran. Peraturan Menteri Pendidikan Nasional No. 16 Tahun 2007 tentang Standar Kualifikasi Akademik dan Kompetensi Guru, diharapkan kinerja guru semakin meningkat dan baik.

Dalam kaitan dengan proses belajar mengajar hendaknya guru dapat mengarahkan dan membimbing siswa untuk aktif dalam kegiatan belajar mengajar sehingga tercipta suatu interaksi yang baik antara guru dengan siswa maupun siswa dengan siswa. Hal ini senada juga ditulis Madri M dan Rosmawati (2004: 274), bahwa terjadinya proses pembelajaran itu ditandai dengan dua hal yaitu : (1) siswa menunjukkan keaktifan, seperti tampak dalam jumlah curahan waktu untuk melaksanakan tugas ajar, (2) terjadi perubahan perilaku yang selaras dengan tujuan pengajaran yang diharapkan.

Pada kenyataannya dari hasil temuan di lapangan masih banyak guru yang belum mampu menerapkan metode-metode pembelajaran dengan baik. Kondisi tersebut juga terjadi di SMP Negeri 3 Pasie Raya Kecamatan Pasie Raya Kabupaten Aceh Jaya. Dari 18 (delapan belas) guru, 3 (tiga) orang diantaranya selalu menggunakan metode 
pembelajaran dengan metode ceramah, tanya jawab, diskusi dan diakhiri dengan pemberian tugas. Pemberian materi juga lebih terpusat pada guru. Kemampuan guru dalam mengembangkan strategi pembelajaran melalui pemilihan metode, media, alat peraga, maupun sumber belajar belum optimal. Dengan kondisi demikian, jika dibiarkan maka akan menghambat proses pembelajaran dimana hasil belajar tidak akan dicapai dengan maksimal.

Berdasarkan uraian di atas maka penulis tertarik untuk mengadakan Penelitian Tindakan Sekolah dengan judul "Upaya Meningkatkan Kemampuan Guru dalam Penggunaan Metode Pembelajaran Melalui Supervisi Klinis di SMP Negeri 3 Pasie Raya Kecamatan Pasie Raya Kabupaten Aceh Jaya Tahun Pelajaran 2018/2019”.

\section{Tujuan Penelitian}

Tujuan yang ingin dicapai dalam penelitian ini adalah: untuk mengetahui upaya peningkatan kemampuan guru dalam penggunaan metode pembelajaran melalui supervisi klinis.

\section{KAJIAN PUSTAKA}

\section{Kemampuan Guru SMP dalam Kegiatan Belajar Mengajar}

Kemampuan sering disebut dengan kompetensi. Menurut Abdul Majid (2005: 56) kompetensi adalah seperangkat tindakan inteligen penuh tanggung jawab yang harus dimiliki seseorang sebagai syarat untuk dianggap mampu melaksanakan tugas-tugas dalam bidang pekerjaan tertentu. Sifat inteligen harus ditunjukkan sebagai kemahiran, ketepatan dan keberhasilan bertindak. Sifat tanggung jawab harus ditunjukkan sebagai kebenaran tindak baik dipandang dari sudut ilmu pengetahuan, teknologi maupun etika.

Menurut Cece Wijaya (1991: 35), secara garis besar mengelompokkan 10 kompetensi dasar yang harus dimiliki oleh seorang guru yaitu:

a. Mampu menguasai mata pelajaran

b. Mampu mengelola program belajar mengajar

c. Mampu mengelola kelas

d. Mampu mengelola dan menggunakan media serta sumber belajar

e. Mampu menilai prestasi belajar

f. Mampu mengenal dan menyelenggarakan administrasi sekolah

g. Mengenal fungsi layanan bimbingan dan konseling di sekolah

h. Mengelola interaksi-interaksi belajar mengajar

i. Menguasai landasan-landasan pendidikan

\section{Metode Pembelajaran}

Terjadinya proses belajar sebagai upaya untuk memperoleh hasil belajar sesungguhnya sulit untuk diamati karena ia berlangsung di dalam mental. Sehubungan dengan hal ini, para ahli cenderung menggunakan pola tingkah laku manusia sebagai suatu model yang menjadi prinsi-prinsip belajar. Untuk mengoptimalkan proses belajar salah satu alternatif yang dilakukan adalah dengan memilih metode belajar yang tepat dan sesuai dengan tujuan pembelajaran.

Metode mengajar adalah cara yang dipergunakan guru dalam mengadakan hubungan dengan siswa pada saat berlangsungnya pembelajaran (Nana Sudjana, 2005: 76). Metode yang ideal dalam belajar sebagaimana dikemukakan oleh Dewey (Samuel Smith, 1986: 260) memiliki ciri: 1. Murid harus benar-benar tertarik pada kegiatan, 2. Pengalaman atau pekerjaan yang edukatif ia harus menemukan dan memecahkan kesukaran atau masalah, 3. Mengumpulkan data-data melalui ingatan pemikiran dan 
pengalaman pribadi atau penelitian, 4. Menentukan cara pemecahan kesukaran atau masalah, 5. Mencoba cara terbaik untuk memecahkan sesuatu melalui penerapan dalam pengalaman, percobaan atau kehidupan sehari-hari.

\section{Supervisi Klinis}

Menurut Piet A. Sahertian, dkk (2000: 17) supervisi adalah usaha dari pertugaspetugas sekolah dalam memimpin guru-guru dan petugas-petugas lainnya dalam memperbaiki pengajaran, termasuk menstimulasi, menyeleksi pertumbuhan jabatan dan perkembangan guru-guru serta merevisi tujuan-tujuan pendidikan, bahan pengajaran atau metode serta evaluasi pengajaran.

Supervisi juga didefinisikan sebagai bantuan dari para pemimpin sekolah, yang tertuju kepada perkembangan kepemimpinan dan personel sekolah lainnya agar mencapai tujuan pendidikan (Ngalim Purwanto, 2009: 76).

Supervisi klinis adalah bentuk supervisi yang difokuskan pada peningkatan mengajar dengan melalui siklus yang sistematik, dalam perencanaan, pengamatan serta analisis yang intensif dan cermat tentang penampilan mengajar yang nyata, serta bertujuan mengadakan perubahan dengan cara yang rasional (Piet A. Sahertian, 2008: 36).

Richard Waller (dalam Ngalim Purwanto, 2009: 90), memberikan definisi tentang supervisi klinis adalah supervisi yang difokuskan pada perbaikan pengajaran dengan melalui siklus yang sistematis dari tahap perencanaan, pengamatan, dan analisis intelektual yang intensif terhadap penampilan mengajar sebenarnya dengan tujuan untuk mengadakan modifikasi rasional (Clinical surervision may $b$ defined as supervision focused upn the improvement if instruction by means of systematic cycles of planning, observation and intensive intellectual analysis of actual teaching performances in the interest of ration modification).

\section{METODE PENELITIAN}

\section{Tempat dan Waktu Penelitian}

Penelitian ini dilaksanakan di SMP Negeri 3 Pasie Raya Kecamatan Pasie Raya Kabupaten Aceh Jaya. Penelitian ini dilaksanakan pada tanggal 4 Februari 2018 s/d 3 Maret 2018.

\section{Subyek Penelitian}

Subyek yang diteliti pada pelaksanaan Penelitian Tindakan Sekolah ini, adalah sebagai berikut: kepala sekolah (dirinya sendiri), guru kelas VII, VIII, dan IX yaitu : guru wali kelas VII (Sdri. Dra. Rahimah), guru wali kelas VIII (Sdri. Budi Immawati, S.Ag), dan guru wali kelas IX (Sdra. Azhari, S.Pd), dengan jumlah siswa kelas VII 10 siswa, kelas VIII 12 siswa, dan kelas IX 13 siswa.

\section{Teknik Pengumpulan Data}

Teknik yang digunakan untuk mengumpulkan data meliputi observasi, wawancara, dan dokumentasi.

\section{Teknik Analisis Data}

Teknik analisis data dilakukan dengan melakukan analisis SWOT, yang terdiri dari unsur-unsur S-Strength (kekuatan), W-Weaknesses (kelemahan), O-Opportuniy (kesempatan), T-Threat (ancaman). Empat hal tersebut dilihat dari sudut kepala sekolah yang melaksanakan dan guru yang dikenai tindakan (Suharsimi Arikunto, 2008: 7). 


\section{HASIL PENELITIAN DAN PEMBAHASAN Kegiatan Siklus I}

Tahap-tahap pelaksanaan penelitian tindakan sekolah untuk meningkatkan kemampuan guru dalam penggunaan metode pembelajaran pada guru wali kelas VII, VIII, dan IX SMP Negeri 3 Pasie Raya Kecamatan Pasie Raya Kabupaten Aceh Jaya.

\section{Perencanaan}

Berdasarkan hasil supervisi awal yang dilaksanakan pada saat kunjungan kelas di kelas VII, VIII, dan IX SMP Negeri 3 Pasie Raya Kecamatan Pasie Raya Kabupaten Aceh Jaya, ditemukan permasalahan sebagai berikut:

a. Pembelajaran terpusat kepada guru

- Metode yang digunakan belum sesuai dengan tujuan pembelajaran

- Pembinaan dalam menetapkan metode yang tepat dan sesuai dengan tujuan pembelajaran belum diterapkan dengan baik oleh guru.

- Melalui refleksi terhadap hasil supervisi awal, peneliti melakukan diskusi dengan guru-guru lain termasuk guru wali kelas VII, VIII, dan IX serta guru pengamat untuk memperoleh kesepakatan cara meningkatkan kemampuan guru dalam menggunakan metode pembelajaran.

Sebagai pendukung pelaksanaan supervisi pada siklus I, peneliti mempersiapkan perencanaan yang disesuaikan dengan kondisi yang ada. Berikut ini perencanaan yang disusun untuk melaksanakan supervisi pada siklus I:

\section{a. Guru}

- Mempersiapkan RPP sesuai dengan mata pelajaran.

- Mempersiapkan lembar informasi tentang supervisi

- Mempersiapkan kriteria RPP yang tepat

- Mempersiapkan kondisi pelaksanaan belajar mengajar untuk mengimplementasikan RPP dalam kegiatan pembelajaran.

b. Pengamat:

- Mempersiapkan lembar pelaksanaan supervisi

- Mempersiapkan lembar observasi

- Mempersiapkan lembar wawancara

- Mempersiapkan penilaian

\section{Pelaksanaan}

a. Pelaksanaan Supervisi Klinis di Kelas VII

Sesuai dengan kesepakatan, pelaksanaan supervisi klinis pada guru wali kelas VII (Sdri. Dra. Rahimah) pada tanggal 07 Februari tahun 2018, dengan tujuan melakukan pengamatan terhadap kemampuan guru dalam menggunakan metode pembelajaran. Pada pelaksanaan kegiatan supervisi klinis di kelas VII, peneliti melakukan supervisi terhadap kemampuan guru dalam menggunakan metode pembelajaran yang berhubungan dengan mapel Pkn dengan Materi Pembuatan rancangan produk kerajinan yaitu:

\section{Kompetensi Dasar :}

2.4 Menghargai keberagaman suku,agama, ras,dan antargolongan dalam bingkai Bhinneka Tunggal Ika

3.4 Mengidentifikasi keberagaman suku, Keberagaman masyarakat Indonesia dalam bingkai Bhinneka Tunggal Ika.

Indikator :

2.4.1 Memiliki keinginan kuat untuk mempelajari keberagaman suku, agama, ras, dan antargolongan dalam bingkai Bhinneka Tunggal Ika.

2.4.2 Memiliki sikap tidak membedakan teman yang berbeda suku, agama, dan ras. 
3.4.1. Mendeskripsikan keberagaman masyarakat Indonesia.

3.4.2. Menganalisis factor penyebab keberagaman masyarakat Indonesia.

3.4.3. Mendeskripsikan keberagaman suku dalam masyarakat Indonesia.

3.4.4. Mendeskripsikan keberagaman ras dalam masyarakat Indonesia.

3.4.5. Menganalisis keberadaan antargolongan dalam masyarakat Indonesia.

3.4.6. Mendeskripsikan makna Bhinneka Tunggal Ika.

3.4.7. Menunjukkan arti penting keberagaman dalam bingkai Bhinneka Tunggal Ika.

Tujuan Pembelajaran

1. Mengidentifikasi factor penyebab keberagaman masyarakat Indonesia

2. Menganalisis keberagaman masyarakat Indonesia.

3. Memahami makna Bhinneka Tunggal Ika.

4. Mengidntifikasi keberagaman ras dalam masyarakat Indonesia

5. Membuat laporan hasil telaah keberagaman suku, agama, ras, dan antar- golongan dalam bingkai Bhinneka Tunggal Ika.

Pelaksanaan supervisi terhadap kemampuan guru menerapkan metode pembelajaran dilakukan sejak kegiatan awal sampai kegiatan akhir pelajaran PKn.

b. Pelaksanaan Supervisi Klinis di Kelas VIII

Pada pelaksanaan kegiatan supervisi klinis di kelas VIII, Sdri. Budi Immawati, S.Ag, guru melakukan presentasi terhadap kemampuan guru dalam menggunakan metode pembelajaran yang berhubungan dengan mapel PAI. Pelaksanaan supervisi klinis terhadap kemampuan guru dalam menggunakan metode pembelajaran PAI pada tanggal 08 Februari 2018, dengan perincian sebagai berikut:

Kompetensi Dasar :

1.10 Melaksanakan sujud syukur, sujud tilawah, dan sujud sahwi sebagai perintah agama.

2.10 Menghayati perilaku santun sebagai implementasi dari sujud syukur, sujud tilawah, dan sujud sahwi.

3.10 Memahami tata cara sujud syukur, sujud tilawah, dan sujud sahwi.

Indikator :

1.10.1 Bersyukur atas segala nikmat yang dianugerahkan dan segala marabahaya yang dihindarkan oleh Allah sebagai implementasi pelaksanaan sujud syukur

1.10.2 Menyadari manusia makhluk yang lemah dihadapan Allah sebagai implementasi pelaksanaan sujud sahwi

1.10.3 Mendekatkan diri kepada Allah dengan menghayati makna ayat-ayat al-Qur'an sebagai implementasi pelaksanaan sujud tilawah.

3.10.10 Membedakan Sujud Syukur, Sahwi, Tilawah

Tujuan Pembelajaran :

1.10.1 Meningkatkan rasa syukur atas segala nikmat yang dianugerahkan dan segala marabahaya yang dihindarkan oleh Allah sebagai implementasi pelaksanaan sujud syukur

1.10.2 Meningkatkan kesadaran bahwa manusia makhluk yang lemah dihadapan Allah sebagai implementasi pelaksanaan sujud sahwi

1.10.3 Mendekatkan diri kepada Allah dengan menghayati makna ayat-ayat al-Qur'an sebagai implementasi pelaksanaan sujud tilawah.

3.10.10 Membedakan Sujud Syukur, Sahwi, Tilawah

Pelaksanaan supervisi klinis dilakukan sejak awal kegiatan pembelajaran sampai pada kegiatan akhir. 


\section{c. Pelaksanaan Supervisi Klinis di Kelas IX}

Pelaksanaan kegiatan supervisi klinis di kelas IX, Sdra. Azhari, S.Pd, guru melakukan presentasi terhadap kemampuan guru menggunakan metode pembelajaran pada mata pelajaran IPA. Kegiatan supervisi klinis pada guru kelas IX dilaksanakan pada tanggal 10 Februari 2018, dalam materi Perbedaan teks cerita moral/fabel dengan teks cerpen dilihat dari struktur isi dan bahasanya.

\section{Kompetensi Dasar :}

1.1. Mengagumi keteraturan dan kompleksitas ciptaan Tuhan tentang aspek fisik dan kimiawi, kehidupan dalam ekosistem, dan peranan manusia dalam lingkungan serta mewujudkannya dalam pengamalan agama yang dianutnya

2.1 Menunjukkan perilaku ilmiah (memiliki rasa ingin tahu, objektif, jujur, teliti, cermat, tekun, hati-hati, bertanggung jawab, terbuka, kritis, kreatif, inovatif, dan peduli lingkungan) dalam aktivitas sehari-hari.

2.2 Menghargai kerja individu dan kelompok dalam aktivitas sehari-hari sebagai wujud implementasi melaksanakan percobaan dan melaporkan hasil percobaan.

2.3 Menunjukkan perilaku bijaksana dan bertanggung jawab dalam aktivitas seharihari.

2.4 Menunjukkan penghargaan kepada orang lain dalam aktivitas sehari-hari

3.10Mendeskripsikan tentang penyebab terjadinya pemanasan global dan dampaknya bagi ekosistem.

1.13Menyajikan data dan informasi tentang pemanasan global dan memberikan usulan penanggulangan masalah.

Indikator :

1. Mengidentifikasi lapisan-lapisan penyusun atmosfer bumi (KI-3;KD-3.10)

2. Mengidentifikasi aktivitas yang menyebabkan terjadinya pemanasan global (KI$3 ; \mathrm{KD}-3.10)$

3. Mengidentifikasi dampak-dampak yang ditimbulkan oleh pemanasan global (KI$3 ; \mathrm{KD}-3.10)$

4. Mempresentasikan hasil analisis data dan informasi tentang pemanasan global (KI$4 ; \mathrm{KD}-4.13)$

5. Menyebutkan langkah-langkah penanggulangan pemanasan global (KI-4;KD-4.13)

Tujuan Pembelajaran :

1. Mengidentifikasi lapisan-lapisan penyusun atmosfer bumi melalui tayangan film atmosfir bumi

2. Mengidentifikasi aktivitas yang menyebabkan terjadinya pemanasan global melalui tayangan film tentang pemanasan global

3. Mengidentifikasi dampak-dampak yang ditimbulkan oleh pemanasan global melalui tayangan film tentang pemanasan global

4. Mempresentasikan hasil analisis data dan informasi tentang pemanasan global melalui diskusi tayangan film pemanasan global

5. Menyebutkan langkah-langkah penanggulangan pemanasan global melalui tayangan film pemanasan global

\section{Pengamatan dan Evaluasi}

Pengamatan dan Evaluasi terhadap pelaksanaan pembelajaran di kelas VII

a. Hasil Pengamatan

Melakukan pengamatan terhadap guru dalam pembelajaran

Pelaksanaan pengamatan terhadap guru dilaksanakan selama pelaksanaan kegiatan pembelajaran yang meliputi kegiatan awal, kegiatan inti, dan kegiatan akhir. Kegiatan pembelajaran yang terdiri dari kegiatan awal, kegiatan inti dan kegiatan akhir 
dilaksanakan dengan baik. Guru melakukan supervisi tentang bagaimana cara guru mengelola kelas sehingga kegiatan belajar benar-benar berjalan dengan efektif.

Mengamati metode pembelajaran yang digunakan

Pengamatan metode pembelajaran difokuskan pada kemampuan guru dalam memilih metode pembelajaran, dengan indikator penilaian yang ditetapkan. Dari hasil pengamatan terhadap kemampuan guru dalam menggunakan metode pembelajaran pada pelaksanaan pembelajaran dalam materi PKn dengan tujuan agar siswa dapat melengkapi cerita dengan memperhatikan hubungan antara makna kalimat yang satu dengan kalimat lainnya dan siswa dapat menentukan judul yang sesuai berdasarkan gambar seri hasilnya masih dalam kategori "kurang" dengan nilai 2,55 karena berada dalam interval score yaitu 2,38-2,77.

b. Evaluasi

Mengacu pada hasil supervisi klinis untuk meningkatkan kemampuan guru dalam menggunakan metode pembelajaran, setelah dilakukan kunjungan kelas untuk mengetahui kemampuan guru dalam menggunakan metode maka dapat diperoleh catatan sebagai berikut:

- Indikator yang sudah dikuasai

- Kesesuaian antara metode dengan tujuan pembelajaran

- Metode dapat melibatkan siswa aktif dalam pembelajaran

- Metode yang digunakan dapat meningkatkan hasil belajar siswa

- Indikator yang belum dikuasai

- Kesesuaian metode dengan materi; disini guru sudah menerapkan beberapa metode agar kegiatan pembelajaran tidak terpusat pada guru dan siswa diarahkan untuk lebih aktif namun metode yang digunakan belum sesuai dengan materi. Maksudnya, metode tersebut tidak bisa membawa siswa lebih memahami materi yang diajarkan.

- Metode belum memotivasi belajar siswa,

- Metode belum mengefektifkan kegiatan pembelajaran

Dari indikator yang belum dikuasai, maka diperlukan suatu metode yang bisa melibatkan siswa secara aktif dalam kegiatan pembelajaran dan membawa siswa lebih mudah dalam memahami materi.

Metode pembelajaran yang digunakan sudah sesuai dengan RPP yang disusun namun metode yang diterapkan belum optimal. Guru perlu memilih metode yang tepat dan sesuai dengan tujuan pembelajaran, pengembangan kemampuan terhadap materi pembelajaran. Beberapa metode yang dapat diterapkan antara lain; pendekatan keterampilan proses, metode kontekstual, metode pendekatan terpadu dan sebagainya.

Pengamatan terhadap pelaksanaan pembelajaran di kelas VIII

a. Hasil Pengamatan

Melakukan pengamatan terhadap guru dalam pembelajaran

Kegiatan pengamatan di kelas VIII dilakukan saat guru melaksanakan kegiatan pembelajaran dalam materi PAI. Pada saat guru melaksanakan kegiatan pembelajaran, guru membuka pelajaran dengan baik, melakukan apersepsi kemudian memotivasi anak. Guru sekilas menjelaskan materi yang akan dibahas. Pada kegiatan inti, guru melakukan eksplorasi, elaborasi dan konfirmasi. Kegiatan penutup dilakukan dengan melakukan kesimpulan terhadap pembelajaran, melakukan evaluasi dan tindak lanjut.

Hasil pengamatan terhadap metode pembelajaran yang digunakan guru dan hasil pengamatannya mengacu hasil pengamatan terhadap kemampuan guru kelas VIII 
dalam menggunakan metode pembelajaran pada pelaksanaan pembelajaran dalam materi bahasa inggris dan kemampuan guru dalam menggunakan metode pembelajaran masih "kurang", dengan nilai rata-rata 2,67.

b. Evaluasi

Berdasarkan hasil pengamatan terhadap pelaksanaan supervisi klinis, diperoleh catatan sebagai berikut:

- Indikator yang sudah dikuasai

- Kesesuaian antara metode dengan tujuan pembelajaran

- Metode dapat memotivasi belajar siswa

- Metode dapat melibatkan siswa dalam pembelajaran

- Metode dapat meningkatkan hasil belajar siswa

- Indikator yang belum dikuasai

- Kesesuaian metode dengan materi

- Metode dapat mengefektifkan pembelajaran

Dari metode yang belum dikuasai, maka diperlukan adanya sifat terbuka dari guru tentang latar belakang permasalahan yang ada sehingga dapat dicari solusi terbaik agar metode pembelajaran yang diterapkan lebih maksimal.

Pengamatan terhadap pelaksanaan pembelajaran di kelas IX

a. Hasil Pengamatan

Melakukan pengamatan terhadap guru dalam pembelajaran

Kegiatan pengamatan di kelas IX dilakukan saat guru melaksanakan kegiatan pembelajaran dalam mapel IPA. Pada saat guru melaksanakan kegiatan pembelajaran, guru membuka pelajaran dengan baik, melakukan apersepsi kemudian memotivasi anak. Guru menjelaskan materi yang akan dibahas. Pada kegiatan inti, guru melakukan eksplorasi, elaborasi dan konfirmasi. Kegiatan penutup dilakukan dengan melakukan kesimpulan terhadap pembelajaran, melakukan evaluasi dan tindak lanjut.

Mengacu hasil pengamatan terhadap kemampuan guru kelas IX dalam menggunakan metode pembelajaran pada pelaksanaan pembelajaran mata pelajaran IPA, kemampuan guru dalam menggunakan metode pembelajaran masih "kurang", dengan nilai rata-rata 2,67. Membandingkan metode dalam RPP dengan penerapannya pada kegiatan pembelajaran.

b. Evaluasi

Berdasarkan hasil pengamatan terhadap pelaksanaan supervisi klinis, diperoleh catatan sebagai berikut:

- Indikator yang sudah dikuasai

- Kesesuaian antara metode dengan tujuan pembelajaran

- Metode dapat melibatkan siswa dalam pembelajaran

- Metode dapat meningkatkan hasil belajar siswa

- Metode dapat mengefektifkan pembelajaran

- Indikator yang belum dikuasai

- Metode dapat memotivasi belajar siswa

- Kesesuaian metode dengan materi

Dari metode yang belum dikuasai, maka diperlukan adanya pembinaan secara individual agar kemampuan guru dapat ditingkatkan lagi sehingga pembelajaran dapat berhasil dengan maksimal. Dalam kegiatan pembelajaran matematika di kelas IX, guru sudah menerapkan beberapa metode dengan asumsi dapat memaksimalkan hasil belajar siswa. Hal tersebut sudah efektif hanya perlu ditingkatkan lagi agar hasil belajar lebih maksimal. 


\section{Refleksi}

Dari hasil pelaksanaan supervisi klinis pada upaya peningkatan kemampuan guru dalam menggunakan metode pembelajaran diketahui bahwa pada siklus I, guru sudah berusaha untuk meningkatkan kemampuannya dalam mengunakan metode pembelajaran.

Dari hasil observasi di kelas VII diketahui bahwa guru belum menerapkan seluruh metode yang terdapat dalam RPP. Selain itu pelaksanaan kegiatan pembelajaran juga masih membutuhkan metode yang tepat dan sesuai dengan tujuan pembelajaran, sehingga diperlukan adanya diskusi antara peneliti (kepala sekolah) dengan guru agar secara bersama-sama dapat mengatasi permasalahan yang ada.

Dari hasil observasi di kelas VIII diketahui bahwa metode konstruktivisme dan inquiri yang tercantum dalam RPP belum diterapkan ketika pelaksanaan pembelajaran. Dari temuan tersebut maka diperlukan suatu keterbukaan dari guru untuk mendiskusikan kealpaan tersebut dilatarbelakangi oleh masalah apa (misalnya: ketidakmampuan guru/keterbatasan waktu, dan sebagainya) sehingga dapat dipecahkan secara bersama-sama masalah yang ada.

Dari hasil observasi di kelas IX guru juga belum menguasai seluruh indikator yang dinilai selama kegiatan supervisi klinis. Metode pembelajaran yang tercantum dalam RPP juga belum dioptimalkan karena ada satu metode yang terlewat yaitu tugas individual. Selain temuan-temuan tersebut, guru juga belum menerapkan metode yang baru yang benar-benar dapat melibatkan siswa secara aktif dalam kegiatan pembelajaran dan mampu memotivasi siswa untuk belajar materi-materi yang berhubungan dengan mapel IPA.

Dari temuan-temuan yang ada, maka diperlukan adanya upaya perbaikan untuk meninkatkan kemampuan guru dalam menggunakan metode pembelajaran sehingga penelitian tindakan sekolah dengan menerapkan pendekatan supervisi klinis harus dilanjutkan lagi pada siklus kedua.

\section{Kegiatan Siklus II}

Tahap-tahap pelaksanaan penelitian tindakan sekolah untuk meningkatkan kemampuan guru dalam penggunaan metode pembelajaran pada guru kelas VII, VIII, dan IX SMP Negeri 3 Pasie Raya Kecamatan Pasie Raya Kabupaten Aceh Jaya.

\section{Perencanaan}

Mengacu pada hasil supervisi pada siklus I di kelas VII, VIII, dan IX SMP Negeri 3 Pasie Raya Kecamatan Pasie Raya Kabupaten Aceh Jaya, diketemukan permasalahan sebagai berikut:

a. Guru belum optimal dalam menggunakan metode pembelajaran.

b. Metode pembelajaran yang terdapat dalam RPP belum dioptimalkan penerapannya.

c. Guru belum berani menggunakan metode pembelajaran yang lebih variatif sehingga hanya terpusat pada diskusi, ceramah, tanya jawab, dan pemberian tugas.

Melalui refleksi terhadap hasil supervisi siklus I, peneliti melakukan diskusi dengan guru-guru kelas VII, VIII, dan IX serta guru pengamat untuk memperoleh kesepakatan cara meningkatkan kemampuan guru dalam menggunakan metode pembelajaran.

Sebagai pendukung pelaksanaan supervisi pada siklus II, peneliti mempersiapkan perencanaan yang disesuaikan dengan kondisi yang ada. Berikut ini perencanaan yang disusun untuk melaksanakan supervisi pada siklus II:

\section{Guru}

- Mempersiapkan RPP sesuai dengan mata pelajaran. 
- Mempersiapkan lembar informasi tentang supervisi

- Mempersiapkan kriteria RPP yang tepat

- Mempersiapkan kondisi pelaksanaan belajar mengajar untuk mengimplementasikan RPP dalam kegiatan pembelajaran.

2. Pengamat

- Mempersiapkan lembar pelaksanaan supervisi

- Mempersiapkan lembar observasi

- Mempersiapkan lembar wawancara

- Mempersiapkan penilaian

\section{Pelaksanaan}

Pelaksanaan Supervisi Klinis di Kelas VII

Pelaksanaan supervise klinis pada siklus II dilaksanakan tanggal 26 Februari 2018. Pada pelaksanaan kegiatan supervisi klinis di kelas VII, peneliti melakukan supervisi terhadap kemampuan guru dalam menggunakan metode pembelajaran mata pelajaran Prakarya dengan materi yang sama seperti di siklus I.

Pelaksanaan supervisi terhadap kemampuan guru menerapkan metode pembelajaran dilakukan sejak kegiatan awal sampai kegiatan akhir pelajaran bahasa Indonesia.

Pelaksanaan Supervisi Klinis di Kelas VIII

Pada pelaksanaan kegiatan supervisi klinis pada guru kelas VIII dilakukan pada tanggal 28 Februari 2018, pada mata pelajaran PAI. Pelaksanaan supervisi klinis terhadap kemampuan guru dalam menggunakan metode pembelajaran pada materi PAI, dengan kompetensi dan indicator yang sama seperti pada kegiatan siklus I.

\section{Pelaksanaan Supervisi Klinis di Kelas IX}

Pelaksanaan kegiatan supervise klinis terhadap upaya peningkatan kemampuan guru dalam menggunakan metode pembelajaran dilaksanakan pada tanggal 29 Februari 2018 dengan sampel pada pelaksanaan materi yang berhubungan dengan mapel Ilmu Pengetahuan Alam (IPA)

\section{Pengamatan dan Evaluasi}

Pengamatan dan Evaluasi terhadap pelaksanaan pembelajaran di kelas VII

\section{Hasil Pengamatan}

Melakukan pengamatan terhadap guru dalam pembelajaran

Pelaksanaan pengamatan terhadap guru dilaksanakan selama pelaksanaan kegiatan pembelajaran yang meliputi kegiatan awal, kegiatan inti, dan kegiatan akhir, dengan mengamati pelaksanaan kegiatan pembelajaran. Hasil pengamatan tertuang dalam ceck list sebagai tolak ukur tingkat keberhasilan guru dalam melaksanakan kegiatan pembelajaran.

Dari hasil pengamatan terhadap kemampuan guru dalam menggunakan metode pembelajaran pada pelaksanaan pembelajaran mata pelajaran PKn dengan tujuan agar siswa dapat melengkapi cerita dengan memperhatikan hubungan antara makna kalimat yang satu dengan kalimat lainnya dan siswa dapat menentukan judul yang sesuai berdasarkan gambar seri hasilnya masih dalam kategori "sangat memuaskan" dengan nilai rata-rata 3,67 karena berada dalam interval score yaitu 2,78-3,27.

2. Evaluasi

Mengacu pada hasil supervisi klinis untuk meningkatkan kemampuan guru dalam menggunakan metode pembelajaran, setelah dilakukan kunjungan kelas untuk 
mengetahui kemampuan guru dalam menggunakan metode maka dapat diperoleh catatan sebagai berikut:

a. Guru sudah menguasai seluruh indikator yang dinilai, dengan hasil yang "memuaskan".

b. Kemampuan guru dalam menerapkan metode juga memberikan efek positif terhadap siswa berupa peningkatan motivasi dan keaktifan yang selanjutnya menjadi nilai tambah guna meningkatkan prestasi belajar siswa.

c. Metode pembelajaran yang digunakan sudah sesuai dengan RPP yang disusun. Guru sudah memilih metode yang tepat dan sesuai dengan tujuan pembelajaran, pengembangan kemampuan berbahasa antara lain menerapkan metode CTL.

Pengamatan terhadap pelaksanaan pembelajaran di kelas VIII

\section{Hasil Pengamatan}

Melakukan pengamatan terhadap guru dalam pembelajaran

Kegiatan pengamatan terhadap kemampuan guru kelas VIII dalam menggunakan metode pembelajaran dilaksanakan pada tanggal 26 Februari 2018. Pada saat guru melaksanakan kegiatan pembelajaran, guru membuka pelajaran dengan baik, melakukan apersepsi kemudian memotivasi anak. Guru sekilas menjelaskan materi yang akan dibahas. Pada kegiatan inti, guru melakukan eksplorasi, elaborasi dan konfirmasi. Kegiatan penutup dilakukan dengan melakukan kesimpulan terhadap pembelajaran, melakukan evaluasi dan tindak lanjut. Mengacu hasil pengamatan terhadap kemampuan guru kelas VIII dalam menggunakan metode pembelajaran pada pelaksanaan pembelajaran mata pelajaran PAI, sudah "sangat memuaskan" dengan nilai rata-rata 3,67 .

2. Evaluasi

Berdasarkan hasil pengamatan terhadap pelaksanaan supervisi klinis, diperoleh catatan sebagai berikut:

a. Guru sudah menguasai seluruh indikator yang dinilai, dengan hasil yang "sangat memuaskan".

b. Kemampuan guru dalam menerapkan metode juga memberikan efek positif terhadap siswa berupa peningkatan motivasi dan keaktifan yang selanjutnya menjadi nilai tambah guna meningkatkan prestasi belajar siswa.

c. Metode pembelajaran yang digunakan sudah sesuai dengan RPP yang disusun. Guru sudah memilih metode yang tepat dan sesuai dengan tujuan pembelajaran.

Peningkatan kemampuan guru dalam menggunakan metode pembelajaran menunjukkan bahwa pelaksanaan supervisi klinis dengan memperhatikan aspek kebutuhan guru dan diskusi antara kepala sekolah dengan guru memberikan efek yang positif terhadap perkembangan kemampuan guru.

Pengamatan terhadap pelaksanaan pembelajaran di kelas IX

1. Hasil Pengamatan

Melakukan pengamatan terhadap guru dalam pembelajaran

Kegiatan pengamatan untuk mengetahui kemampuan guru kelas IX dalam menggunakan metode pembelajaran dilaksanakan pada tanggal 2829 Februari 2018. Mengacu hasil pengamatan terhadap kemampuan guru kelas IX dalam menggunakan metode pembelajaran pada pelaksanaan pembelajaran mata pelajaran IPA hasilnya sudah "sangat memuaskan" dengan rata-rata skor 3,50.

2. Evaluasi 
Berdasarkan hasil pengamatan terhadap pelaksanaan supervisi klinis, diperoleh catatan sebagai berikut:

Guru sudah menguasai seluruh indikator yang dinilai, dengan hasil yang "sangat memuaskan". Kemampuan guru dalam menerapkan metode juga memberikan efek positif terhadap siswa berupa peningkatan motivasi dan keaktifan yang selanjutnya menjadi nilai tambah guna meningkatkan prestasi belajar siswa kelas IX yang akan menempuh ujian akhir.

Metode pembelajaran yang digunakan sudah sesuai dengan RPP yang disusun. Guru sudah memilih metode yang tepat dan sesuai dengan tujuan pembelajaran.

Peningkatan kemampuan guru dalam menggunakan metode pembelajaran menunjukkan bahwa pelaksanaan supervisi klinis dengan memperhatikan aspek kebutuhan guru dan diskusi antara kepala sekolah dengan guru memberikan efek yang positif terhadap perkembangan kemampuan guru dalam meningkatkan kemampuan menggunakan metode pembelajaran.

\section{Refleksi}

Dari hasil pelaksanaan supervisi klinis pada upaya peningkatan kemampuan guru dalam menggunakan metode pembelajaran diketahui bahwa pada siklus II, guru sudah berusaha untuk meningkatkan kemampuannya dalam mengunakan metode pembelajaran, dan hasilnya sangat memuaskan.

Dari hasil observasi di kelas VII diketahui bahwa guru sudah menerapkan seluruh metode yang terdapat dalam RPP. Selain itu pelaksanaan kegiatan pembelajaran juga sudah menerapkan fasiasi metode sehingga kegiatan pembelajaran yang dilaksanakan lebih maksimal.

Dari hasil observasi di kelas VIII diketahui bahwa kemampuan guru dalam menguasai metode pembelajaran sudah meninkat dengan hasil perolehan score "sangat memuaskan". Hal itu ditunjukkan dari kemampuan guru melakukan kegiatan pembelajaran dengan tepat dan menerapkan seluruh metode yang ada di RPP sehingga pembelajaran memperolehhasil yang maksimal.

Dari hasil observasi di kelas IX guru juga sudah mampu menguasai seluruh indikator yang dinilai selama kegiatan supervisi klinis. Metode pembelajaran yang tercantum dalam RPP juga sudah dioptimalkan karena ada satu metode yang terlewat yaitu tugas individual. Dari temuan-temuan yang ada, maka pelaksanaan penelitian tindakan sekolah dengan menerapkan supervisi klinis guna meningkatkan kemampuan guru dalam menggunakan alat peraga dapat diakhiri pada siklus II.

\section{Pembahasan}

Pelaksanaan supervisi klinis pada dasarnya difokuskan pada perbalikan pengajaran dengan melalui siklus yang sistematis dari tahap perencanaan, pengamatan, dan analisis intelektual yang intensif terhadap penampilan mengajar sebenarnya dengan tujuan mengadakan modifikasi rasional.

Berkaitan dengan pelaksanaan kegiatan supervisi klinis di SMP Negeri 3 Pasie Raya, target yang diharapkan adalah kemampuan guru dalam menggunakan metode pembelajaran dengan asumsi bahwa melalui penerapan metode yang tepat maka proses ekplorasi, elaborasi dan konfirmasi dalam kegiatan inti pembelajaran dapat dioptimalkan sehingga prestasi belajar siswa menjadi meningkat.

Dasar pertimbangan pengembangan profesionalisme guru pada indikator tersebut karena guru merupakan ujung tombak dalam peningkatan kualitas pembelajaran dan penanam nilai-nilai dasar pada pendidikan sekolah dasar yang selanjutnya akan sangat bermanfaat bagi perkembangan anak didiknya di masa yang akan datang. 
Dari hasil pelaksanaan supervisi klinis pada studi awal, siklus I, dan siklus II, pada grafik berikut ini:

\section{Rata-rata Kemampuan Guru dalam Menggunakan Metode Pembelajaran}

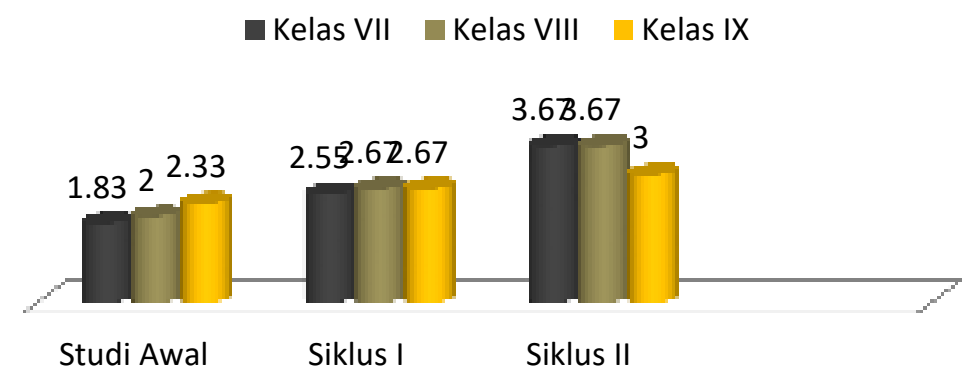

Gambar Persentase Kemampuan Guru Menguasai Indikator dalam RPP

Melalui pencapaian tersebut, maka tujuan dari supervisi klinis yang antara lain membantu guru mengembangkan kompetensinya, dapat tercapai dengan optimal. Hal tersebut juga dikemukakan oleh guru setelah pelaksanaan observasi, sebagai berikut:

Berkaitan dengan kemampuan guru dalam menggunakan metode pembelajaran, guru wali kelas VII (Sdri. Dra. Rahimah) menyatakan sebagai berikut:

Melalui latihan, bimbingan dan dukungan pada kegiatan supervisi kemampuan kami dalam menggunakan alat peraga menjadi lebih maksimal. (wawancara tanggal 26 Februari 2018)

Guru wali kelas VIII, (Sdri. Budi Immawati, S.Ag), memberikan penyataan berkaitan dengan kemampuan dalam menggunakan metode pembalajaran sebagai berikut Beberapa indikator yang semula kurang kami pahami, saat ini sudah bisa dipahami dengan baik. Kami juga bisa menerapkan seluruh metode yang sudah tercatat dalam RPP. (wawancara tanggal 28 Februari 2018). Dan guru wali kelas IX, Sdra. Azhari, S.Pd, memberikan pernyataan tentang kemampuan menyusun RPP sebagai berikut beberapa metode baru kami terapkan, dan hal tersebut ternyata hasilnya luar biasa terhadap peningkatan keaktifan dan motivasi siswa untuk belajar. Ini tentu sangat positif karena kelas IX merupakan masa-masa menjelang ujian nasional yang butuh kesungguhan siswa dalam memahami materi. (wawancara tanggal 29 Februari 2018).

Dari hasil wawancara tersebut, maka secara garis besar melalui kegiatan supervisi klinis diperoleh catatan sebagai berikut:

- Kemampuan guru dalam menggunakan metode pembelajaran meningkat.

- Guru lebih menguasai indikator dalam penguasaan metode pembelajaran.

- Guru dapat memilih metode yang tepat dan sesuai dengan tujuan pembelajaran.

- Guru lebih terbuka saat mendapatkan permasalahan khususnya dalam penentuan metode pembelajaran.

\section{Kesimpulan}

Mengacu pada hasil penelitian tindakan sekolah melalui kegiatan pembinaan akademik, disimpulkan yaitu keberhasilan sebuah kegiatan pembelajaran dipengaruhi oleh banyak faktor, baik faktor yang dating dari guru, siswa, maupun kepala sekolah sebagai pemimpin di sekolah. Salah satu peranan kepala sekolah dalam kegiatan pembelajaran adalah melakukan upaya perbaikan pembelajaran guru dengan menerapkan pendekatan supervisi, diantaranya supervisi klinis. Metode pembelajaran merupakan salah satu komponen yang sangat mempengaruhi keberhasilan kegiatan 
belajar mengajar, karena di dalamnya memuat strategi agar anak didik dapat belajar secara efektif dan esifien. Peningkatan kemampuan guru dalam menggunakan metode pembelajaran melalui supervisi klinis merupakan salah satu solusi yang cukup efektif. Hal tersebut dapat dilihat dari hasil akhir penelitian dimana guru dapat menguasai indikator yang ada dalam menentukan metode pembelajaran dan mencari metode yang benar-benar tepat dan sesuai dengan tujuan pembelajaran serta kondisi lingkungan kelas dan lingkungan sekolah itu sendiri yang selanjutnya memberikan manfaat bagi peningkatan prestasi belajar siswa dan peningkatan mutu sekolah.

\section{DAFTAR PUSTAKA}

Abdul Majid, 2005. Perencanaan Pembelajaran. Bandung: Remaja RoSMPakarya

Arikunto, Suharsimi. 2002. Prosedur Penelitian, Suatu Pendekatan Praktek. Jakarta: PT Rineka Cipta.

Cece. Wijaya. (1991). Kemampuan Dasar Guru Dalam Proses Belajar. Mengajar. Bandung : PT Remaja Rosda karya.

Madri M. dan Rosmawati. 2004. Jurnal Pembelajaran. Desember. Vol. 27, No. 03, h. 274.

Nana Sudjana, 2005. Strategi Pembelajaran. Bandung: Alfabeta

Ngalim Purwanto, 2009. Administrasi dan Supervisi Pendidikan. Bandung: Remaja RoSMPakarya

Piet A. Sahertian, 2000. Konsep Dasar dan Teknik Supervisi Pendidikan Dalam Rangka Pengambangan Sumber Daya Manusia. Jakarta: Rineka Cipta

Samuel Smith, mengjarkan-matematika-sebuah-pemikiran.html diakses dari http://chamisah.blogspot.com 